\title{
The applications of appropriate renewable energy technologies by the refugees and displaced persons under humanitarian assistance programmes
}

\author{
Namiz Musafer ${ }^{1}$, Nihal Samaratunga ${ }^{1}$, P. G. Ajith Kumara ${ }^{2}$ \\ ${ }^{1}$ Energy Managers, and Integrated Development Associations, Sri Lanka \\ ${ }^{2}$ Simple Engineering (Pvt) Ltd
}

\begin{abstract}
Sri Lanka is an island country situated south of India which has experienced with a large number of refugees and internally displaced persons especially since 1983 due to natural and human induced disasters and events from time to time. This study explores and describes how the displaced communities were supplied with appropriate renewable energy technologies to meet their energy demands as against the electricity generated from diesel generators or by providing expensive petroleum gases which contribute towards environmental pollution and greenhouse gas emissions while them being comparatively expensive. This study adopted a 'single longitudinal case study in retrospect' research approach. As sustainable energy solutions, providing of fuelwood based energy efficient clay cook stoves, solar photovoltaic lighting and water pumping, solar dryers, biogas systems, small wind turbines, and solar-wind hybrids have been introduced to them on an ad hoc basis depending on the interests and priorities of the supporting agencies. The existing national policies do not place an adequate specific attention to the meeting of energy needs of the displaced communities of Sri Lanka.
\end{abstract}

\section{INTRODUCTION}

Q ri Lanka, an island country situated south of India, has had a large number of refugees and internally displaced persons [hereinafter commonly referred to as 'displaced communities'] for many years which have been induced byarmed conflict, natural disasters or development schemes. Conflict induced displacement of persons began in 1915 with an ethnic violence, followed by riots in 1958 displacing 12,000 persons (Shamini, 2012). In August 1977, she experienced another conflict-induced displacement due to an ethnic violence in many parts of the country leading to the displacement of about 25,000 persons (Schroder \& Stark, 2016). The volume of displacement radically changed in July 1983 in the history of Sri Lankan conflict called 'Black July', causing a larger scale displacement (Shamini, 2012). At the end of 1997, there had been 787,877 officially registered internal refugees in Sri Lanka (van Brabant 1998: 151 as cited in Schrijvers, 1999). The Indian Ocean tsunami resulted in a natural disaster induced displacement of over 500,000 persons in 2004 , and due to the military operations, over 220,000 persons from the eastern province during 2006-2007, and over 280,000 (estimated) persons from northern and eastern provinces during 2008 - 2009 were displaced in Sri Lanka(Schroder \& Stark, 2016). Apart from these major occurrences, other conflict triggered (Ex. riots, ethnic conflicts) and natural disasters (Ex. floods, landslides, cyclones) have transformed thousands of persons into displaced communities.

The scholars have argued for an integrated approach to return and recovery of the displaced communities fostering a new social order (Ex. Price, 2010). During early stages of being affected, displaced communities are accommodated in very basic temporary shelter such as tents or huts, and subsequently with the help of donor agencies or the government, they are shifted into semi-permanent small houses that have been constructed using cadjan(woven coconut leaves) or zinc sheets for the roofs (Wanninayake, 2017\& 2019).

In certain cases the displaced families were assisted with or provided with new houses, while whose houses were partially or fully damaged, the house owners were provided with grants or other assistance for the repair or reconstruction of their houses (Ratnasooriya et al., 2007).

The state of energy access among displaced communities suggest that they have little access to electricity and clean cooking (Grafham \& Vianello, 2018). At the same time, the energy they use is economically, environmentally and socially unsustainable and most of their camps are reliant on poorly planned and inefficient diesel solutions to power the facilities, while improving access to cleaner and more modern energy solutions would lead to reduced costs and emissions cuts, and such sustainable energy solutions reduce environmental and social pressures and create opportunities for local businesses (Lahn and Grafham, 2015). For those face situations where repatriation or return is not feasible, there is a need for longer term solutions like integration with the hostcommunity(Wanninayake, 2017 \& 2019), as integrating the refugees into local society could be a durable solution for their future (Valatheeswaran \& Rajan, 2011)

Short-term, politically oriented humanitarian funding is poorly suited to financing longer-term energy solutions in protracted crises and recovery situations (Lahn and Grafham, 2015). However, because the policy makers and government authorities had focused on repatriation, host community integration had become an almost forgotten option for displaced communities of Sri Lanka (Wanninayake, 2017 \& 
2019). From the global perspective, it is estimated that over $90 \%$ of those displaced communities living in camps do not have access to electricity, and over $80 \%$ of such people around the world have to cook with the most basic cooking fuels (Lahn and Grafham, 2015; Lehne et al., 2016).

The experience world over has shown that access to energy resources and energy services remain a serious challenge under humanitarian settings for both the displaced communities and humanitarian agencies engaged in field operations. When a disaster strikes or conflicts devastate the infrastructure, one of the first services that may become unavailable for the affected communities is the electric power supply (Musafer \& Gurmu, 2020). Therefore, with the increased frequency and intensity of disasters, one of the main priorities after a disaster is the supply of electricity (Ozcelik, 2017). However, aftermath of a disaster pose a monumental challenge of restoration of public services to maintain health and support other recovery activities (Berke at al., 1993) that include restoration of electricity infrastructure.

In Sri Lanka, one of the initial steps in providing access to electricity to the affected communities who were living in areas where there had not been access to the national electricity grid was the introduction of power generators with distribution lines erected along temporary poles. These communities have been supported for wiring and supply of light bulbs to illuminate the family homes with light (Reliefweb, 2005). However, the communities relying on diesel power generators had to rely on oil which were to be purchased from the markets at a price. This was an issue for affected communities who lost their livelihoods and could not afford to pay for the expensive fuels. Locally available renewable energy sources could serve as a better sustained solution to meet the energy requirements of the displaced communities.

\section{AIM}

The main objective of this study was to explore and describe how the displaced communities were supplied with appropriate renewable energy technologies to meet their energy demands as against generating electricity from diesel generators or by providing expensive petroleum gases which contribute towards environmental pollution and greenhouse gas emissions while being comparatively expensive.

\section{METHODOLOGY}

The case study research method allows the questions of 'why', 'what' and 'how' to be answered with a relatively full understanding of the nature and complexity of the complete phenomenon (Bebensat, 1987 as cited in Voss et al., 2002), where a case study is a unit of analysis in case research (Leonard-Barton, 1990). Case research has consistently been one of the most powerful research methods where field research studies are carried out in an iterative approach frequently involving multiple methods of data collection, multiple researchers and an evolution of concepts and constructs (Voss et al., 2002).

The situation in Sri Lanka pertaining to displaced communities was considered to describe the interventions or phenomenon using the real-life context in which it occurred (Yin, 2003 as cited in Baxter \& Jack, 2008). A choice in case selection is whether to use retrospective or current cases. Retrospective cases allow for more controlled case selection, for example it is possible to identify cases that reflect either success or failure only in retrospect (Voss et al., 2002). The retrospective studies offer the opportunities in the identification of patterns indicative of dynamic processes while the longitudinal studies provide a close-up view of those patterns as they evolve over time, and the combination of the two enhances the constrict, internal, and external validities (Leonard-Barton, 1990).

Themeting of energy needs is aligned with the subject of displaced communities in Sri Lanka, whichhave triggered sporadically and sustained constantly over a long time. Accordingly, this study adopts a longitudinal case study in retrospect. The appropriate renewable energy technologies supplied to the displaced communities considered under this paper are from the eastern, northern, and southern provinces who had experienced at-least a conflict induced disaster or the 2004 tsunami or both while those from the southern province had experienced the tsunami.

Appropriate renewable energy technologies supplied to the displaced communities

The diverse energy needs of the displaced communities could be met using different energy technologies. There are many factors to be considered in this endeavor, such as technology factors, social factors, institutional regulatory aspects, site suitability, economic \& financial feasibilities, and achievability by the specific supporting organisations (Barry et al., 2009). The technologies that were provided in the Sri Lankan context are identified as follows.

\section{(i). Cooking - stoves}

Access to food is one the first needs the communities affected by a disaster would attempt to fulfill. Unless food is directly supplied, such communities would prefer preparing their own meals for which water and food material, fuels (energy) and cooking facilities (infrastructure - Ex. Stoves, cookers) are required. It is a common practice to supply dry food rations to those affected. As for energy for cooking, the internally displaced communities in camps and resettlement areas in Sri Lanka depended on fuelwood, almost exclusively (WFP, 2017). The most used approach by the communities was to use fuelwood for cooking due to some possibilities of getting them supplied or collected from the surroundings. Where possible, fuelwood was complemented by coconut shells and other parts of coconut trees and palm leaves. Collection of fuelwood from certain neighborhoods were risky due to the exposure to the uncleared landmines and unexploded 
ordnances. Further, those who have limited living space after the disasters had to cook, live, and sleep at the same place where they sleep as there was no separate area to be used as a kitchen. Cooking using inefficient mixed fuel in low efficient cook stoves lead to indoor air quality issues with consequences from the emitted smoke and other matter for those who live around.Considering these, some affected communities had been assisted with improved cook stoves to prepare their meals that consume less amounts of fuels compared to traditional cooking (WFP, 2017). One of the greatest advantages of these stoves are them being portable, so that they could be taken once the affected communities settle in permanent shelters or in other forms of dwelling systems, these being very affordable and available from the local markets. These features make themto be replaced easily too. Although cooking using biogas, Liquefied Petroleum Gas or electricity would have led to a cleaner living environment, they are much expensive threatening affordability by the poor, and in their limited access and availability.

Different humanitarian agencies assisted in helping the communities meet their energy demands for preparation of their food in different ways. As an immediate measure, the communities were provided with the improved cook stoves. These were made by the local potters using clay. Their fuel efficiencies were nearly double, and emissions were lower compared to the conventional (threestone)stoves, leading to the use of lesser fuelwood and lesser emissions of smoke. Going beyond mere supply of stoves, in certain areas, the communities were trained on production of clay cook stoves and development of a sustainable source of fuelwood from home garden based social forestry (WFP, 2017). Biomass institutional cookstoves had also been installed for mass cooking to provide mid-day meals to school students.

\section{(ii). Solar Lighting \& Water Pumping}

Solar lighting is an expensive, but quicker solution to meet lighting needs of those affected by a disaster, particularly if there is a reasonable solar irradiation in the areas concerned. Use of solar lights does not contribute to emissions at the places of use. One of the greatest challenges in providing solar lighting was the initial investment cost. Smaller needs of lighting were met by solar lanterns with a small solar PV panel and small in-built battery storage. The household lighting needs were provided by Solar PV panels of various sizes depending on the projects that assisted the communities. The houses were fitted with about 3-8 bulbs of lower wattage, and often worked on direct current (DC) rather than on alternating current (AC) as in the case of the supply of national electricity grid. The systems were helpful in illuminating homes, children's education, and safety of people (Ex. ability to see snakes) too. The designers were reluctant to convert the energy stored in the batteries to AC through an inverter due to the additional cost of the inverters and loss of energy in the conversion process. In addition to using solar energy for lighting, solar panel also had been used for pumping water sourced from the ground.

\section{(iii). Watch TVs, Listen to Radios \& Charging Mobile Phones}

The communities, where possible, made uses of stored energy in batteries to watch $\mathrm{TV}$, listen to radios, charge their mobile phones etc., with necessary adopters. Where the grid electricity was available nearby or in a nearby town, they used to charge the batteries from time to time and use them at homes. Where they had direct access to solar PV battery charging units, they charged the batteries at homes, using renewable energy.Prior to access to renewable energy, the communities spend about LKR 18,000 to purchase a battery which had a lifetime of about 2 years. On average, these were charged twice a month at a cost of LKR 100 per a charging cycle with an additional cost of about LKR 100 for transport. This amounted to a cost of about LKR 1,150 per month for capital and maintenance.This was a significant amount as a percentage of their monthly incomes.

\section{(iv). Solar Dryers}

Open-air solar drying of fruits, vegetable, and fish had widely been used from ancient times in Sri Lanka. In the case of fish, this techniquehas been used in the preparation of dried fish to preserve fish where the fish is dehydrated to prevent the growth of microorganisms. The fisher communities used to perform open-air solar drying by spreading their produce on the beaches or floors. This technique does not help much control of the process. This also can lead to production losses and degradation of the quality of the produce. Open-air drying (ex. beach) expose the fishdirectly to the sun's Ultra Violet rays and many contaminations such as dust, dirt, insects, birds, fungi and to bad weather (Talbot et al., 2016). There were potential issues with ability to dry during day time, but fungi to develop in nights too. To overcome these problems of sun drying,solar dryers had been introduced to small-scale fisher communities, including those who were affected by disasters.

Solar-drying involves with drying of produce in an enclosed ventilated area quite often with a polythene covering. For the fisher communities, 2 main models of solar dryers had been introduced in Sri Lanka along the coastal areas to preserve the sea fish harvested from the Indian Ocean, the Stationary Dryer of $100 \mathrm{~kg}$ and Mobile (Collapsible) Dryer of $50 \mathrm{~kg}$ of capacities.

The structure of the $100 \mathrm{~kg}$ capacity dryer was quite similar to a gable roofed greenhouse with a structure of $7.8 \mathrm{~m}$ in length, $4.7 \mathrm{~m}$ of width and $2.6 \mathrm{~m}$ of height, and the ridge being about $3.6 \mathrm{~m}$. The floor constructed of paved brick and covered with a cement rendering was elevated from the ground level. The walls, of which the outer side was painted black for greater heat absorption and retention, were of bricks erected on the four sides to support the structure (Practical Action).

The other type of solar dryers introduced to the affected communities were the $50 \mathrm{~kg}$ of batch size Mobile (collapsible) Solar Dryers. Their structure had been similar to the conventional agricultural poly tunnels, and size being $3.8 \mathrm{~m}$ in 
length, $3.1 \mathrm{~m}$ in width, and $1.9 \mathrm{~m}$ in height at the apex. The door of this structure is polythene clad, which is also lockable. The floor is elevated from ground level and is rendered using black cement. The dryers consisted of 4 moveable wooden racks with cascading shelves. Each of them were fixed with 7 shelves made of plastic netted drying surfaces with space provided in and around the racks facilitating ease of loading and unloading (Practical Action).

These dryers helped in reduction in drying time and hassle, while extending the productive time by making it possible to work during rainy days.

\section{(v). Biogas Systems}

Biogas is a technology that converts different types of organic wastes into useful agricultural inputs while releasing methane gas which can be used as a source of energy. Those affected by Tsunami whose cows escaped the disasteror had been donated with milking cows by relief agencies had been provided with biogas systems to manage their organic waste, cow dung. Many of these were of $8 \mathrm{~m}^{3}$ of digester capacity and of fixed dome - continuous flow type.

The biogas slurry, which is also called'bio fertilizer', was used in home gardening for organic food production. Biogas was used for cooking and lighting, and the produced amount of biogas was adequate to meet basic cooking and lighting needs. The stoves used were the liquefied petroleum gas (LPG) cookers purchased from the local markets and converted to be used with biogas with some alterations. For lighting, locally produced lamps were used. Although Sri Lanka had experience with small scale water pumping and power generation using biogas from neighbouring districts, apparently, such applications have not been attempted with those affected by the disaster. Similarly, the toilets were not connected to their biogas systems.

Local technicians from the neighbouring districts constructed the biogas systems where cement, bricks, sand, and iron rods were the main construction material which were available in the local markets and produced or mined locally. The experts guided them on processing of bio fertilizer from the biogas slurry and application of them in organic home gardening. As the communities already had cows, they were also exposed to dairy related cottage industries related to production of dairy products such as milk toffees and curd. They showed interest in producing yoghurt, flavoured milk and ice cream too. The communities were capacitated on marketing their produce and were linked with supply and market chains for their value added products.

The use of biogas also had gone beyond mere consumption for household cooking. Mass cooking for sale of lunch packets as a small business was facilitated by a biogas system from the southern province. The biogas system operated from the cow dung as well as the food waste,helping to maintain waste management and an attractive environment for customers, while enhancing agricultural productivity from organic inputs and food security. On the other hand, biogas systems complemented raring of milking cows at a time the price for liquid milk was not so great to run as a standalone income generating cottage based livelihood option. There had been a tendency for small holders to sell their cows as some of them felt that the return on their efforts on raring cows only for milking was not worthy.

\section{(vi). Small Wind Turbines}

Families affected by civil war from the eastern province and those affected by the tsunami from the coastal areas of the southern provincehave been provided with standalone off-grid small scale household type wind turbines of $200 \mathrm{~W}$ capacity rated at the wind speed of 9 meters per second $\left(9 \mathrm{~ms}^{-1}\right)$. These were locally designed and produced. Materials were purchased from the local market while the magnets for the wind generators had been specifically imported. All were 3 bladed turbines positioned at a hub height of nearly 10 meters(40 feet) above the ground level having a permanent magnet generator. Local technicians from the eastern provincehavealso been trained on their installation and commissioning, operations and maintenance, and attending to smaller repairs.

The electricity generated from these turbines werefirst stored in 70-90 Ampere Hour batteries. These batteries were often used for cars, and were purchased from the local market. Electricity was used after converting stored energy in the battery to alternating current bylocally produced inverters, so that they could use the general household electric appliances. The recipients have had no access to the main grid electricity prior to the disaster, and the self-generated electricity was adequate for them to meet their immediate basic lighting and entertainment (watching TV) energy needs, but they were unable to use higher electricity consuming appliances such as fans, refrigerators, irons, washing machines, and other kitchen appliances etc.,

Communities living as clusters were provided with community-based village wind energy electrification schemes. These were of $2 \mathrm{~kW}$ of capacity rated at wind speed of 9 meters per second $\left(9 \mathrm{~ms}^{-1}\right)$, with 3 blades of diameter of 3.5metres. Each scheme provided electricity to meet basic energy needs of the families. About 10-12 families were connected through a micro electricity grid, backed up by a battery bank of 3000 Ampere Hours (Ah) (a battery bank of 20 batteries of $150 \mathrm{Ah}$ capacity). The stored energy in the batteries were converter to AC current using a $2 \mathrm{~kW}$ DC to AC converter. The electrical house wiring was carried out by local electricians while the powerhouse, battery bank, inverters, and drawing of distribution lines have been designed by local engineers. The work has been carried out under their supervision. The wind turbine generators, inverters, and battery banks have been specifically imported while the rest of the components have been procured from the local markets.

In order to optimise the power generation from wind, placement of small wind turbines at most suitable locations is 
vital, for which a detailed understanding of the spatial variability of the wind resource is required (Drew et al., 2013). Micro siting, in other words identification of the most suitable sites to produce electricity from wind turbines, is quite important in the wind energy technology applications. Small wind turbines are often installed in more complex environments than the open terrain sites (Tabrizi, et al., 2015). It had been hard to locate ideal sites having a good match of higher wind potential and where the affected communities were residing. While most suitable sites for wind turbines are determined after a study of wind characteristics of at-least over 1 year, apart from extrapolating and estimating the average wind speeds of the specific locations, there was hardly any better way of siting implemented in positioning the wind turbines. On the other hand the local vegetation of tall trees and houses located nearby posed resistance to wind that retard the wind speeds, negatively affecting the wind energy potential.

\section{(vii). Solar - Wind Hybrid Systems}

Solar energy is available during the day time when the sun shines. As a measure to use energy during the night time or during days of bad weather, solar energy may be stored in a battery and used at a latter time when needed. At the same time, wind energy may be available throughout the day, although there are diurnal and seasonal variations. Accordingly, these renewable energy sources are unpredictable due to natural conditions. The combined use of the solar and wind (solar - wind hybrid) renewable energy systems are a good option for the utilization these available resources (Wagh \& Walke, 2017) where their weaknesses are traded-off by each other.

Small-scale wind-solar hybrid systems have been introduced in the southern province. The wind turbines were of 3 blades of 2.5 metre diameter and $300 \mathrm{~W}$ of capacity rated at 7 meters per second $\left(7 \mathrm{~ms}^{-1}\right)$ placed at a hub height of6 metres. The cutin wind speed was 3 metres per second. The turbine was rated at 400 rounds per minute. The solar Photovoltaic (PV) panels were of monocrystalline type, and $60 \mathrm{~W}_{\mathrm{p}}$ (Sixty Watts peak) of capacity. The hybrid was backed up by a $110 \mathrm{Wh}$ battery storage system. The wind turbine of these also confronted with the same experience of small wind systems described above with ideal siting and decreased wind speeds. However, having two sources of energy made the users of these systems to have uninterrupted access to electricity for a longer duration compared to those who had either a solar PV panel or a wind turbine.

\section{National policy context}

The Sri Lanka Disaster Management Act has described the functions of the National Council for Disaster Management to include to formulate a national policy and program on the management of disasters which shall inter alia provide for the maintenance and development of disaster-affected areas and the effective use of resources for preparedness, prevention, response, relief, reconstruction and rehabilitation (SLDMA,
2005). According to the national policy, the relevant agencies and organizations should have emergency response systems, plans and programs in place to restore public utilities and essential services that are damaged or destroyed due to disasters under the guidance and facilitation of the Ministry of Disaster (NPDM). However, no special reference to access to energy by the affected communities or restoration of electricity infrastructure is specifically focused in these national documents. Similarly, the National Energy Policy and Strategies of Sri Lanka (NEPS, 2019) too has no such special reference. While Sri Lanka has 3 tiers of governance including the Provincial Councils and Local Government Authorities, they too have no direct reference to addressing energy needs or infrastructure related to those affected by disasters and have become displaced communities. Therefore, attention to provide access to energy to meet energy needs and energy services to them is currently under no one's purview, and therefore is being addressed on a case-by-case ad hoc basis depending on the priorities set and interests of those who want to serve the affected communities.

\section{LIMITATIONS}

A single case study was adoptedfrom 3 out of 9 provinces of a country. These can have the limitations in generalisability of conclusions drawn, biases such as misjudging the representativeness of a single event and exaggerating easily available data (Voss et al., 2002). The general challenges of case studies such as the lack of scientific rigour and having limited basis for generalization of results to a wider context would be applicable to this study too. Further, the research has attempted to capture information pertaining to the provinces, covering a large geographical area while many organisations have been involved in providing many services, including energy services to the affected communities, with a time range of nearly 3 decades. Therefore, there are chances for omissions of some technologies or their specifications, and the inability to capture some of them due to loss of records, and memory of past events.

The study explored the aspects on providing access to energy from different technologies. However, this does not contain any outcome of an evaluation carried out on their current status or use. Over the period, the electrification rate in the country has increased and stood at $99.3 \%$ by the year 2016 which indicate that the off-grid areas in the country are confined only to $0.7 \%$ by then. This rate had been $78 \%$ and $90 \%$ by the years 2006 and 2010 respectively. The per capita electricity consumption also has reached 670.2 kilowatt hours $(\mathrm{kWh})$ per annum by the end of 2019, which had been 394 and $449 \mathrm{kWh}$ in 2006 and 2010 respectively (CBSL, 2007, 2011, 2020).

\section{CONCLUSIONS}

Sri Lanka, at different times in the recent past has demonstrated deployment of different applications of appropriate renewable energy technologies for the refugees and displaced persons under humanitarian assistance 
programmes implemented by various agencies. The type and amount of energy needed and accessed by such communities have varied along with the changes of phases of the aftermaths of natural or human induced disasters. As sustainable energy solutions, providing of fuelwood based energy efficient clay cook stoves, solar photovoltaic lighting and water pumping, solar dryers, biogas systems, small wind turbines, and solar-wind hybrids have been introduced to them as against environmental polluting and expensive diesel generated and main grid electricity where appropriate on an ad hoc basic depending on the interests and priorities of the supporting agencies. The national policies in place do not place adequate specific attention to the meeting of energy needs of the displaced communities of Sri Lanka.

\section{REFERENCES}

[1] Barry, M. L., Steyn, H., and Brent, A., (2009), The use of the focus group technique in management research: the example of renewable energy technology selection in Africa, Journal of Contemporary Management, 6(1), pp. 229 - 240. Available at: https://journals.co.za/docserver/fulltext/jcman/6/1/jcman_v6_a13.p df?expires $=1605459143 \&$ id=id\&accname $=$ guest $\&$ checksum $=$ DB D25B810B7B0C60BF90297F43D09641, Accessed on November $15,2020$.

[2] Baxter, P., and Jack, S., (2008), Qualitative Case Study Methodology: Study Design and Implementation for Novice Researchers, The Qualitative Report, 13(4); pp. 544 - 559.

[3] Berke, P. R., Kartez, J., and Wenger, D., (1993), Recovery after Disasters: Achieving Sustainable Development, Mitigation and Equity, Disasters, 17(2), 93-109. doi: 10.1111/j.14677717.1993.tb01137.x.

[4] Central Bank of Sri Lanka (2007, 2011, 2020), Annual Report 2006, 2010, 2019

[5] Centre for Poverty Analysis - CPA (2017), Review of PBF funded project: "Support for Sri Lanka national reconciliation efforts by addressing grievances of the concerned sections of the population through targeted resettlement of the last of the conflict affected internally displaced persons", Available at https://www.un.org/peacebuilding/sites/www.un.org.peacebuilding /files/documents/sri_lanka_june_2017_-

_evaluation_of_resettlement_of_idps_project.pdf, Accessed on June 22, 2020

[6] Drew, D. R., Barlow, J. F., and Cockerill, T. ., (2013), Estimating the potential yield of small wind turbines in urban areas: A case study for Greater London, UK, Journal of Wind Engineering and Industrial Aerodynamics, 115. C. 104 - 111. ISSN 0167-6105.

[7] European Union and the United Nations - EU \& UN (2018), Technical Report on Statistics of Internally Displaced Persons: Current Practice and Recommendations for Improvement, Available at: https://unstats.un.org/unsd/demographicsocial/Standards-and-Methods/files/Technical-Report/nationalreporting/Technical-report-on-statistics-of-IDPs-E.pdf, Accessed on June 22, 2020.

[8] Grafham, O., and Vianello, M., (2018), Energy for Displacement: Key Issues, Energy For Displacement 'Understanding the Challenges', HEED Briefing Paper No.1, Available at: http://heedrefugee.coventry.ac.uk/wp-content/uploads/2019/09/compressedHEED-Briefing-Paper-September-2018.pdf, Accessed on; November 13, 2020.

[9] Internal Displacement Monitoring Centre and Norwegian Refugee Council - IDMC \& NRC (2020), Global Report on Internal Displacement; Available

https://reliefweb.int/sites/reliefweb.int/files/resources/2020-

IDMC-GRID.pdf, Accessed on June 22, 2020.

[10] International Bank for Reconstruction and Development: The World Bank - (IBRC \& WB) (2017), State of Electricity Access Report; Available http://documentos.bancomundial.org/curated/es/364571494517675 149/pdf/114841-REVISED-JUNE12-FINAL-SEAR-web-REVoptimized.pdf, Accessed on June 23, 2020

[11] Lahn, G., and Grafham, O., (2015), Heat, Light and Power for Refugees Saving Lives, Reducing Costs, Available at: https://www.chathamhouse.org/sites/default/files/publications/rese arch/2015-11-17-heat-light-power-refugees-lahn-grafhamfinal.pdf, Access on November 14, 2020.

[12] Lehne J., Blyth, W., Lahn, G., Bazilian M., and Grafham, O., (2016), Energy services for refugees and displaced people, Energy Strategy Reviews, 13-14; pp. 134-146. Available at: www.sciencedirect.com/science/article/pii/S2211467X16300396, Accessed on November 14, 2020.

[13] Leonard-Barton, D., (1990), A dual methodology for case studies: synergistic use of a longitudinal single site with replicated multiple sites, Organisation Science, 1(1); pp. 248 - 266.

[14] Musafer, N., (2014), Small scale appropriate energy technologies in meeting basic energy needs of Sri Lanka - success and failure factors, National Energy Symposium, Sri Lanka Sustainable Energy Authority, Colombo.

[15] Musafer, N., and Gurmu, D., (2020), Energy Issues and Solutions for Disaster and Conflict Affected Refugees: A Prognosis, International Journal of Innovative Science and Research Technology, 10(5); pp. 1227-1231.

[16] National Council for Disaster Management of Sri Lanka, National Policy on Disaster Management (NPDM); Available at: http://www.disastermin.gov.lk/web/images/pdf/sri\%20lanka\%20di saster\%20management\%20policy\%20english.pdf; Accessed on November 13, 2020.

[17] Ministry of Power, Energy, and Business Development of the Government of Sri Lanka, National Energy Policy and Strategies of Sri Lanka - NEPS (2019)

[18] Ozcelik, M., (2017), Alternative model for electricity and water supply after disaster, Journal of Taibah University for Science, 11:6, 966-974, DOI: 10.1016/j.jtusci.2017.01.002.

[19] Parliament of Democratic Socialist Republic of Sri Lanka, Sri Lanka Disaster Management Act no 13 of 2005; Available at: http://www.unlocked.lk/wp-content/uploads/2019/06/DisasterManagement-Act_E.pdf; Accessed on; November 13, 2020.

[20] Practical Action Sri Lanka, Construction and Maintenance of Solar Fish Dryer - Technical Brief

[21] Price, N., (2010), Integrating 'Return' with 'Recovery': Utilizing the Return Process in the Transition to Positive Peace: A Case Study of Sri Lanka, The Round Table, 99(410); pp. 529 - 545. Available at: https://www.tandfonline.com/doi/pdf/10.1080/00358533.2010.509 948, Accessed on November 15, 2020.

[22] Ratnasooriya, H. A. R., Samarawickrama, S. P., and Imamura, F (2007), Post Tsunami Recovery Process in Sri Lanka, Journal of Natural Disaster Science, 29(1); pp21 - 28. Available at: https://www.jstage.jst.go.jp/article/jnds/29/1/29_1_21/_pdf, Accessed on November 15, 2020.

[23] Red Cross Red Crescent Movement - RCRCM (2006), Tsunami 2 year Progress Report - Sri Lanka; Available at: https://www.ifrc.org/Docs/Appeals/04/2804srilankapr.pdf, Accessed on June 23, 2020.

[24] Reliefweb (2005), Innovative partnerships in Sri Lanka, Available at: https://reliefweb.int/report/sri-lanka/innovative-partnershipssri-lanka; Accessed on: November 13, 2020.

[25] Schrijvers, J., (1999), Fighters, Victims and Survivors: Constructions of Ethnicity, Gender and Refugeeness among Tamils in Sri Lanka, Journal of Refugee Studies, 12(3); pp. 307333.

[26] Schroder, J and Stark, C., (2011), Sri Lanka: Gaps in the Government Response to Post-2007 Internal Displacement, From Responsibility to Response: Assessing National Approaches to Internal Displacement, The Brookings Institution - London School of Economics Project on Internal Displacement, Available at: https://www.brookings.edu/wp-content/uploads/2012/04/FromResponsibility-to-Response-Nov-2011doc.pdf, Accessed on; November 15,2020. 
[27] Shamini, C., (2012), Challenges of IDP Resettlement in Sri Lanka An Examination of Northern Spring Program in Vavuniya District, Journal of International Development and Cooperation, 18(3); pp. 65 - 83. Available at: https://ir.lib.hiroshimau.ac.jp/files/public/3/32474/20141016190308405801/ JIDC_183 65.pdf, Accessed on November 15, 2020.

[28] Tabrizi, A., Whale, J., Lyons, T. and Urmee, T., (2015), Rooftop wind monitoring campaigns for small wind turbine applications: Effect of sampling rate and averaging period. Renewable Energy, 77. pp. $320-330$

[29] Valatheeswaran, C., and Rajan, S. I., (2011), Sri Lankan Tamil Refugees in India: Rehabilitation mechanisms, livelihood strategies, and lasting solutions, Refugee Survey Quarterly, 30(2); pp. 24 - 44. https://doi.org/10.1093/rsq/hdr005.

[30] Verité Research - VR (2018), Policy Note: Natural Disaster Insurance Coverage Solving the Lethargy on Language Policy
Will Help SMEs Island-wide; Available at: https://www.veriteresearch.org/wpcontent/uploads/2018/07/Verit\%C3\%A9-Research-Policy-

Note_Natural-Disaster-Insurance-Coverage-1.pdf, Accessed on June 24, 2020.

[31] Voss, C., Tsikriktsis, N. and Frohlich, M. (2002), "Case research in operations management", International Journal of Operations \& Production Management, Vol. 22 No. 2, pp. 195-219. https://doi.org/10.1108/01443570210414329

[32] Wagh, S., and Walke, P. V., (2017), Review on wind-solar hybrid power system, International Journal of Research in Science \& Engineering, 3(2): pp. 71 - 76.

[33] World Food Programme (2017), Safe Access to Fuel and Energy (SAFE) Sri Lanka, Available at: https://docs.wfp.org/api/documents/WFP-0000070104/download/, Accessed on November 13, 2020. 